\title{
PENGGUNAAN KITOSAN SEBAGAI ADSORBEN PROTEIN PADA LIMBAH CAIR TAHU DESA TINALAN, KOTA KEDIRI
}

\author{
Ibnu Muhariawan Restuaji*, Ira Oktavia \\ Prodi DIII Teknologi Laboratorium Medis, Institut Ilmu Kesehatan Bhakti Wiyata Kediri, Indonesia \\ Prodi S1 Farmasi, Institut Ilmu Kesehatan Bhakti Wiyata Kediri, Indonesia \\ *email : ibnu.muhariawan@iik.ac.id
}

Received 31 August 2020

Accepted 27 October 2020

\begin{abstract}
Abstrak
Protein merupakan senyawa yang banyak terkandung di dalam limbah cair tahu. Kadar protein yang tinggi dapat menyebabkan kenaikan BOD dan COD limbah cair tahu di lingkungan. Penelitian ini bertujuan untuk mengetahui kemampuan kitosan dalam mengadsorpsi protein limbah cair tahu dari Desa Tinalan, Kota Kediri. Awal sebelum perlakuan, kadar protein sampel limbah cair tahu yaitu 0,0904\%. Pada saat adsorpsi, massa kitosan yang digunakan yaitu $0,25 \mathrm{~g} ; 0,5 \mathrm{~g}$; 0,75 g dan $1 \mathrm{~g}$ dengan kode sampel masing-masing kitosan-LCT1; kitosan-LCT2; kitosan-LCT3 dan kitosan-LCT4. Kitosan ditambahkan ke limbah cair tahu dan diaduk selama 8 jam. Hasil penelitian menunjukkan bahwa kitosan-LCT1 lebih efektif dalam mengadsorpsi dibandingkan kitosan lain. Kitosan-LCT1 mampu menurunkan kadar protein dari 0,0904\% menjadi 0,0566\%. Hasil SEM menegaskan bahwa telah terjadi perubahan morfologi permukaan pada kitosanLCT1 yang berbentuk pipih dan guratan putih. Hal ini menunjukkan telah terjadi proses adsorpsi antara kitosan dan protein. Selain itu, adsorpsi juga menyebabkan peningkatan pH limbah cair tahu mencapai $6-7$.
\end{abstract}

Kata kunci : Protein, Limbah Cair Tahu, Kitosan, Adsorpsi

\begin{abstract}
Proteins are the most compound that contained in liquid waste tofu. The high concentration of proteins can increasing BOD and COD liquid waste on the around environment. So that, the aim of this study is observed capability of chitosan to adsorb protein in liquid waste tofu from Tinalan Village, Kediri Town. The initial concentration of proteins are $0,0904 \%$, which determined by spectrophotometer UV-Vis. In the process, the mass of chitosan is $0,25 \mathrm{~g} ; 0,5 \mathrm{~g} ; 0,75 \mathrm{~g}$ and $1 \mathrm{~g}$ that named chitosan-LCT1; chitosan LCT2; chitosan-LCT3 and chitosan-LCT4, respectively. Chitosan was added in liquid waste tofu. After that, the mixture is stirred at 8 hours. The result shows that chitosanLCT1 has more effectively protein adsorption than other chitosan. It reduces the concentration of protein from $0,0904 \%$ to $0,0566 \%$. Meanwhile, the SEM results shows that the surface morphology of chitosan-LCT1 has changed to more thin than other and there is white streak. It shows that there is occurred adsorption process between chitosan and proteins. Besides, the adsorption has affected the enhancement of $\mathrm{pH}$ liquid waste tofu that obtained to $6-7$.
\end{abstract}

Keywords : Proteins, Liquid Waste Tofu, Chitosan, Adsorption

\section{Pendahuluan}

Tahu merupakan salah satu makanan favorit masyarakat Indonesia. Di Jawa
Timur, terdapat kota yang dijuluki sebagai kota tahu, yaitu Kota Kediri. Hal ini dikarenakan potensi hasil pertanian 
kedelai dan sektor industri tahu cukup besar. Pada tahun 2017, luas tanam kedelai Kota Kediri mencapai $14 \mathrm{Ha}$ dan produksinya 42 Ton (BPS Kota Kediri, 2018). Banyak pelaku usaha tahu khususnya home industry yang berkembang di Kediri. Beberapa home industry terdapat di kelurahan Jagalan, Pocanan, Pakelan, Tinalan dan Bawang. Beberapa merk tahu terkenal seperti Bahkacung, Sari Lezat POO, Panglima, Soponyono, LYM, dan masih banyak lagi (BPS Kota Kediri, 2018). Dengan semakin berkembangnya pelaku home industry tahu, perlu diperhatikan tentang pengelolaan limbah yang dihasilkan. Para pelaku home industry tahu masih membuang limbah cair di saluran air, sedangkan limbah padat ditimbun atau dijadikan bahan pakan ternak (Handayani $\&$ Niam, 2018).

Limbah tahu terdiri dari dua jenis yaitu limbah cair dan limbah padat. Limbah padat berasal dari penyaringan dan pengendapan, biasanya dimanfaatkan untuk keperluan lain seperti pakan ternak, tempe gembus, kripik dan tepung. Sedangkan limbah cair berasal dari proses pencucian dan perebusan memiliki kadar TSS, COD, dan BOD yang tinggi (Pamungkas \& Slamet, 2017). Putri, (2018), melaporkan profil limbah cair tahu yaitu kadar TSS 286-365 mg/L, COD 7417-7857 mg/L, BOD $2900 \mathrm{mg} / \mathrm{L}$. Limbah cair tahu tersebut beresiko mencemari lingkungan karena tidak sesuai dengan baku mutu air limbah yang ditetapkan dalam Peraturan Menteri Lingkungan Hidup Nomor 5 Tahun 2014 yaitu kadar BOD $150 \mathrm{mg} / \mathrm{L}$, COD 300 mg/L, TSS 200 mg/L (Kementerian Lingkungan Hidup, 2014).

Tingginya kadar COD dan BOD pada limbah cair tahu dipengaruhi oleh adanya protein dalam tahu. Menurut Sarjono et al., (2006), dalam penelitiannya melaporkan bahwa kadar protein dalam limbah cair tahu mencapai 48,8 \% berat $(\mathrm{g} / \mathrm{g})$. Beberapa penelitian tentang penurunan kadar protein dengan adsorben telah dilakukan, diantaranya adalah menggunakan karbon aktif (Purnawan et al., 2014), pasir silika (Kasman et al., 2018), zeolit (Seroja et al., 2018) dan kitosan (Vega et al., 2013). Kitosan digunakan sebagai adsorben karena sifatnya yang biokompatibel, biodegra-dable, non-toksik, pembuatannya mudah dan ketersediaannya melimpah (Ravi Kumar, 2000). Oleh karena itu, pada penelitian ini kitosan digunakan untuk mengadsorpsi protein yang terdapat dalam limbah cair tahu di Desa Tinalan, Kota Kediri.

\section{Metode Penelitian}

Bahan dan Peralatan

Bahan yang digunakan pada penelitian ini antara lain limbah cair tahu yang diambil dari home industry tahu di Desa Tinalan, Kota Kediri; serbuk kitosan; reagen Biuret; Bovine Serum Albumin (BSA) dan akuademin. Sedangkan alat yang digunakan antara lain gelas piala, kertas saring, erlenmeyer, corong, kertas label, botol semprot, mikrotube, mikropipet, pipet volume, kuvet, magnetic stirrer, stirrer bar, spektrofotometer UVVis dan Scanning Electron Microscope (SEM).

\section{Penentuan Panjang Gelombang Maksimum dan Kurva Standar Protein}

Pada tahap ini menggunakan metode Biuret (Jubaidah et al., 2016) (Fendri et al., 2019). BSA ditimbang sebanyak 0,05 $\mathrm{g}$ dan dilarutkan dalam akuademin $50 \mathrm{~mL}$ sehingga terbentuk larutan induk BSA $0,1 \%$. Dari larutan induk $0,1 \%$, dibuat larutan BSA 0,05\%. Larutan BSA 0,05\% diambil sebanyak $2 \mathrm{~mL}$, ditambahkan 1 $\mathrm{mL}$ reagen Biuret, diinkubasi pada suhu ruang selama 10 menit dan diukur absorbansinya dengan spektrofotometer UV-Vis pada panjang gelombang $500-$ $600 \mathrm{~nm}$. Kemudian diamati panjang gelombang maksimumnya.

Untuk menentukan kurva standar protein, disiapkan 5 gelas piala (beaker 
glass), masing-masing untuk larutan baku BSA $0,01 \% ; 0,02 \% ; 0,03 \% ; 0,04 \%$ dan $0,05 \%$. Diambil $2 \mathrm{~mL}$ larutan baku BSA, ditambahkan $1 \mathrm{~mL}$ reagen Biuret, diinkubasi pada suhu ruang selama 10 menit dan diukur absorbansinya pada panjang gelombang maksimum.

\section{Penentuan Kadar Protein Awal Limbah Cair Tahu}

Sebelum ditentukan kadar proteinnya, limbah cair tahu diukur $\mathrm{pH}$ terlebih dahulu. Setelah itu, limbah cair tahu disaring dengan menggunakan kertas saring. Filtrat diambil sebanyak $10 \mathrm{~mL}$ dan dilarutkan dalam $250 \mathrm{~mL}$ akuademin. Larutan tersebut disaring kembali hingga jernih dan diukur $\mathrm{pH}$. Kemudian filtrat diambil sebanyak $2 \mathrm{~mL}$ dan dianalisa kadar proteinnya dengan spektrofotometer UV-Vis.

\section{Adsorpsi Protein Limbah Cair Tahu dengan Kitosan}

Sebanyak 0,$25 ; 0,5 ; 0,75$ dan $1 \mathrm{~g}$ serbuk kitosan dimasukkan ke dalam masing-masing $20 \mathrm{~mL}$ filtrat limbah cair tahu hasil penyaringan dan pelarutan. Dilakukan pengadukan selama 8 jam menggunakan magnetic stirrer. Setelah itu, campuran disaring hingga jernih. Kemudian filtrat diambil sebanyak 10 $\mathrm{mL}$ untuk diukur $\mathrm{pH}$ dan ditentukan kadar proteinnya menggu-nakan spektrofotometer UV-Vis.

Masing-masing sampel diberi kode yaitu LCT1, LCT2, LCT3 dan LCT4. Dimana LCT1 untuk penggunaan kitosan
0,25 g, LCT2 kitosan 0,5 g, LCT3 kitosan 0,75 g dan LCT4 kitosan $1 \mathrm{~g}$.

Pada tahap ini juga dilakukan analisa SEM kitosan. Analisa SEM dilakukan untuk mengamati morfologi permukaan kitosan sebelum dan sesudah adsorpsi protein limbah cair tahu.

\section{Hasil dan Pembahasan}

Penentuan Panjang Gelombang Maksimum dan Kurva Standar Protein

Berdasarkan Gornall et al., (1948), penentuan panjang gelombang maksimum larutan standar BSA menggunakan reagen Biuret yaitu berada pada rentang 500-600 nm. Seperti ditunjukkan dalam Tabel 1, serapan maksimum Bovine Serum Albumin (BSA) pada penelitian ini didapatkan pada panjang gelombang $540 \mathrm{~nm}$. Hasil tersebut tidak memiliki selisih perbedaan signifikan jika dibandingkan dengan panjang gelombang optimum BSA yang diteliti oleh Sinaga et al., (2015), yaitu $553,36 \mathrm{~nm}$.

Penentuan kurva standar berfungsi untuk mencari regresi linier yang akan digunakan untuk penghitungan kadar protein pada sampel (Sinaga, et al., 2015). Pada penelitian ini larutan standar BSA dianalisis menggunakan panjang gelom-bang maksimum yaitu $540 \mathrm{~nm}$. Seperti pada Gambar 1, hasil analisa menun-jukkan bahwa terdapat korelasi linier antara peningkatan absorbansi dengan seiring penambahan kadar. Nilai $\mathrm{R}^{2}$ dida-patkan sebesar 0,9911 dengan persamaan regresi linier $\mathrm{y}=1,17 \mathrm{x}+$ 0,0275 .

Tabel 1. Hasil pengukuran panjang gelombang dan absorbansi BSA 0,05\%

\begin{tabular}{c|c|c|c}
\hline $\begin{array}{c}\text { Sampel } \\
\text { BSA }\end{array}$ & $\begin{array}{c}\text { Kadar } \\
\text { BSA (\%) }\end{array}$ & Panjang Gelombang (nm) & A \\
\hline 1 & 0,05 & 500 & 0,064 \\
2 & 0,05 & 520 & 0,075 \\
3 & 0,05 & 540 & 0,087 \\
4 & 0,05 & 560 & 0,076 \\
5 & 0,05 & 580 & 0,063 \\
6 & 0,05 & 600 & 0,057 \\
\hline
\end{tabular}




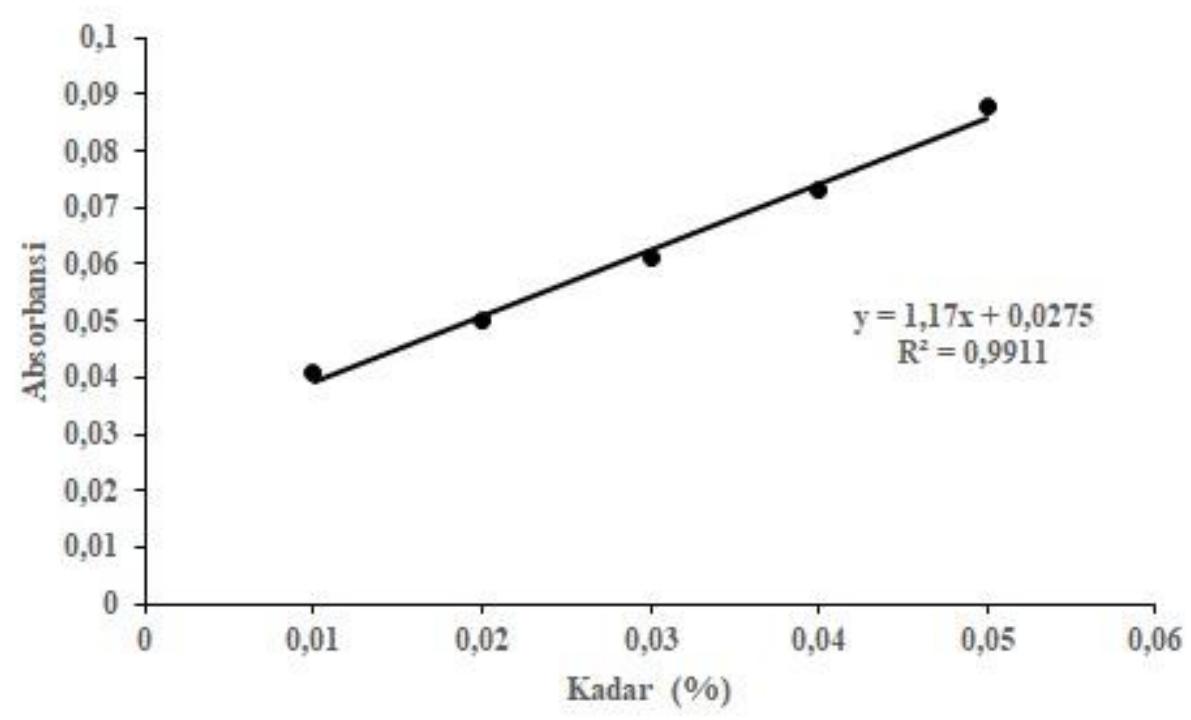

Gambar 1. Kurva standar protein pada panjang gelombang maksimum $540 \mathrm{~nm}$

\section{Penentuan Kadar Protein Awal Limbah Cair Tahu}

Limbah cair tahu dari Desa Tinalan, kota Kediri memiliki sifat fisik berupa cairan, berbau dan keruh. Sifat fisik tersebut umum ditemukan pada limbah cair tahu di industri-industri pengolahan tahu. Hal ini sesuai dengan penelitian Pradana et al., (2018) dan Pamungkas \& Slamet, (2017). Menurut Pradana et al., (2018), dalam limbah cair tahu terdapat zat-zat tersuspensi yang membuat cairan kotor dan keruh. Menurut Pamungkas \& Slamet, (2017), limbah cair tahu memiliki kandungan zat organik yang tinggi. Zat-zat makromolekul organik yang terkandung didalamnya menyebabkan kotor, berbau dan keruh. Oleh karena itu pada penelitian ini dilakukan proses pengenceran dan penyaringan supaya limbah cair tahu dapat dianalisa kadar proteinnya menggunakan spektrofoto-meter UV-Vis.

Sebelum penentuan kadar protein, dilakukan pengukuran $\mathrm{pH}$ awal limbah cair tahu. Didapatkan hasil $\mathrm{pH}$ yaitu 4 , seperti ditunjukkan pada Tabel 2. Namun setelah dilakukan pengenceran dan penyaringan, $\mathrm{pH}$ limbah cair tahu menjadi 5. Rendahnya $\mathrm{pH}$ limbah cair tahu Desa Tinalan disebabkan penggunaan asam asetat $\left(\mathrm{CH}_{3} \mathrm{COOH}\right)$ sebagai bahan penggumpal air kedelai. Hasil pH pada penelitian ini sesuai dengan penelitian yang dilakukan Yudhistira et al., (2016). Pada penelitian tersebut $\mathrm{pH}$ limbah cair tahu sekitar 3,91 karena penggunaan asam asetat sebagai zat penggumpal. Asam asetat lebih banyak digunakan sebagai zat penggumpal karena kemampuan mengko-agulasi protein secara cepat, mudah didapatkan dan murah (Paramitha, 2017).

Tabel 2. Kadar protein awal dan $\mathrm{pH}$ sampel limbah cair tahu

\begin{tabular}{|c|c|c|c|}
\hline \multirow{2}{*}{ Sampel } & $\begin{array}{c}\text { pH sebelum dan sesudah } \\
\text { disaring }\end{array}$ & $\begin{array}{c}\text { Kadar } \\
\text { protein } \\
(\%)\end{array}$ \\
\cline { 2 - 3 } & Sebelum & Sesudah & 0,0927 \\
\hline 1 & 4 & 5 & 0,0850 \\
\hline 2 & 4 & 5 & 0,0936 \\
\hline 3 & 4 & 5 & $\mathbf{0 , 0 9 0 4}$ \\
\hline \multicolumn{3}{|c|}{ Rata-rata } \\
\hline
\end{tabular}

Filtrat, hasil pengenceran dan penyaringan, dianalisa dengan spektrofotometer UV-Vis pada panjang gelombang maksimum $540 \mathrm{~nm}$. Hasilnya, kadar protein awal (rata-rata) limbah cair tahu yaitu $0,0904 \%$, seperti ditunjukkan pada Tabel 2. Kadar protein awal limbah cair 
tahu pada penelitian ini lebih rendah bila dibandingkan dengan penelitian Mulyaningsih et al., (2013), (0,42\%) dan Mujtahidah \& Kusuma, (2019), (0,39\%). Hal ini dikarenakan limbah cair tahu harus diencerkan dan disaring beberapa kali sampai filtrat jernih sebelum analisa spektrofotometer UV-Vis.

\section{Adsorpsi Protein Limbah Cair Tahu dengan Kitosan}

Adsorpsi protein limbah cair tahu dilakukan dengan mencampurkan serbuk kitosan dan $20 \mathrm{~mL}$ limbah cair tahu hasil pengenceran dan penyaringan. Campuran diaduk menggunakan magnetic stirrer selama 8 jam. Variasi massa kitosan 0,$25 ; 0,5 ; 0,75$ dan $1 \mathrm{~g}$ dilakukan dengan kode sampel LCT1, LCT2, LCT3 dan LCT4. LCT1 merupakan campuran antara limbah dan 0,25 g kitosan. LCT2 adalah campuran antara limbah dan $0,5 \mathrm{~g}$ kitosan. LCT3 adalah campuran antara limbah dan 0,75 g kitosan. LCT4 adalah campuran antara limbah dan $1 \mathrm{~g}$ kitosan. Tujuan dari variasi massa kitosan adalah untuk mengetahui massa kitosan yang optimum dalam mengadsorp protein limbah cair tahu.

Hasil adsorspi protein limbah cair tahu dengan kitosan ditunjukkan Tabel 3 . Kitosan pada LCT1 menunjukkan kemampuan adsorpsi protein yang baik dibandingkan kitosan pada LCT2, LCT3 dan LCT4. Kitosan-LCT1 mampu menurunkan kadar protein sampel dari $0,0904 \%$ menjadi $0,0566 \%$. Hal ini menunjukkan bahwa dengan massa kitosan 0,25 g mampu menurunkan kadar protein sampel limbah cair tahu sebesar $37,78 \%$.

Tabel 3. Kadar protein dan $\mathrm{pH}$ sampel limbah cair tahu sesudah adsorpsi

\begin{tabular}{|c|c|c|}
\hline Sampel & Kadar protein $(\boldsymbol{\%})$ & $\mathbf{p H}$ \\
\hline LCT1 & 0,0566 & 6 \\
\hline LCT2 & 0,1252 & 6 \\
\hline LCT3 & 0,1141 & 7 \\
\hline LCT4 & 0,1184 & 7 \\
\hline
\end{tabular}

Adsorpsi protein pada kitosan-LCT1 terjadi secara kimia atau kemisorpsi. Jenis adsorpsi ini terjadi karena adanya ikatan kimia antar molekul adsorben dan adsorbat sehingga membentuk suatu ikatan yang kuat serta irreversible. Ikatan yang terjadi antara protein dan kitosan yaitu ikatan hidrogen. Ikatan tersebut melibatkan gugus amida (-CO-NH) pada protein dan gugus hidroksil $(-\mathrm{OH})$ pada kitosan (Mardyaningsih et al., 2014).
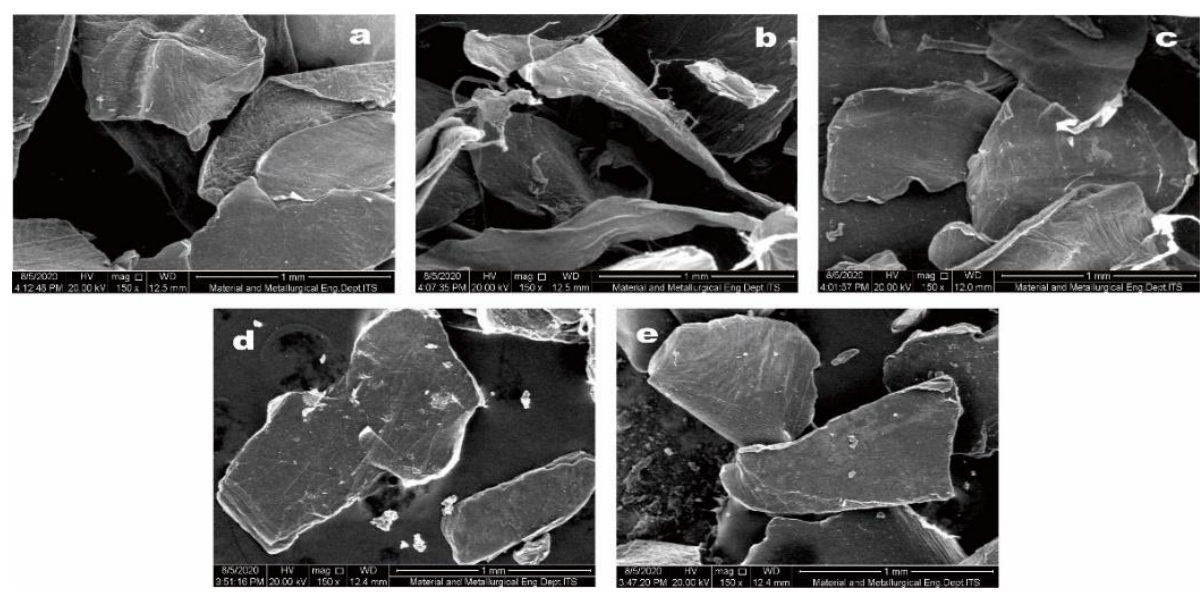

Gambar 2. Mikrograf SEM ; a) kitosan, b) kitosan-LCT1, c) kitosan-LCT2, d) kitosanLCT3, d) kitosan-LCT4 
Gugus hidroksil (-OH) menjadikan reaktivitas kimia dan sifat polielektrolit kitosan tinggi. Atom $\mathrm{O}$ pada gugus hidroksil kitosan memiliki sifat elektronegativitas tinggi dan mampu memberikan gaya tarik antar atom (Iriana et al., 2018). Pada gugus amida (-CO$\mathrm{NH})$ protein, atom $\mathrm{H}$ memiliki elektronegativitas yang lemah. Hal ini menyebabkan atom $\mathrm{O}$ gugus hidroksil kitosan mudah mengikat atom $\mathrm{H}$ gugus amida protein. Menurut Nastiti \& Siahaan, (2015), energi ikatan antara gugus amida protein dan trimer kitosan diperkirakan mencapai 74,765 kJ/mol. Sedangkan Yopianto et al., (2016), melaporkan pada penelitiannya bahwa energi ikatan antara protein dan kitosan mencapai 41,5616 $\mathrm{kJ} / \mathrm{mol}$. Fenomena tersebut menjelaskan terjadinya ikatan hidrogen antara protein dan kitosan-LCT1. Sehingga pada penelitian ini, komposisi massa 0,25 g kitosan efektif dalam mengadsorpsi protein pada limbah cair tahu.

Hasil yang berbeda ditunjukkan pada kitosan-LCT2, kitosan-LCT3 dan kitosan-LCT4. Tabel 3 menunjukkan bahwa semakin besar massa kitosan yang digunakan, kadar protein limbah cair tahu justru semakin meningkat. Kadar protein limbah cair tahu pada tiga sampel tersebut masing-masing; 0,1252\%; $0,1141 \%$ dan $0,1184 \%$. Meningkatnya kadar protein disebabkan karena tingginya komposisi massa kitosan yang digunakan. Kitosan yang berikatan dengan peptida akan melepas atom $\mathrm{H}$ karena sifat elektronega-tivitasnya yang rendah. Semakin banyak kitosan yang digunakan, berbanding lurus dengan banyaknya atom $\mathrm{H}$ yang terlepas. Kelebihan atom $\mathrm{H}$ menyebabkan gugus amin (-NH) protein menangkapnya sehingga terbentuk semakin banyak protein. Hal ini sesuai dengan penelitian Mardyaningsih et al., (2014), bahwa semakin banyak kitosan yang digunakan semakin tinggi protein yang terbentuk.

Sampel juga memiliki $\mathrm{pH}$ yang semakin meningkat, seperti ditunjukkan
Tabel 3. Hal ini dikarenakan protein memiliki sifat isoelektrik dengan adanya gugus karboksil dan gugus amin (Nastiti et al., 2015). Meningkatnya $\mathrm{pH}$ dipengaruhi oleh banyaknya gugus amin yang menangkap proton (atom $\mathrm{H}$ ) yang berasal dari kitosan. Pratiwi et al., (2018), menyatakan bahwa interaksi gugus amin dan atom $\mathrm{H}$ yang berlebih dapat meningkatkan $\mathrm{pH}$ protein menjadi 8-10. Hal ini juga menunjukkan bahwa adsorpsi kitosan-protein tidak hanya dapat meningkatkan kadar protein tetapi juga dapat meningkatkan $\mathrm{pH}$ limbah cair tahu.

Analisa morfologi permukaan kitosan sebagai adsorben protein pada limbah cair tahu dilakukan dengan Scanning Electron Microscope (SEM). Gambar 2 menun-jukkan hasil SEM dari kitosan; kitosan-LCT1; kitosan-LCT2; kitosanLCT3 dan kitosan-LCT4. Berdasarkan mikrograf tersebut, hanya kitosan-LCT1 yang memiliki morfologi berbeda dibandingkan empat sampel lainnya. Morfologi permukaan kitosan-LCT1 berbentuk lebih pipih dan terdapat guratan putih. Berbeda dengan morfologi empat sampel lainnya yang cenderung sama yaitu berbentuk lebih lebar. Hasil mikrograf tersebut mendukung penjelasan bahwa pada kitosan-LCT1 terjadi kemisorpsi antara kitosan dan protein sehingga merubah bentuk morfologi permukaannya.

\section{Kesimpulan}

Berdasarkan hasil penelitian disimpulkan bahwa massa optimum kitosan dalam mengadsorpsi protein limbah cair tahu yaitu 0,25 g. Dengan massa tersebut, terjadi penurunan kadar protein dari $0,0904 \%$ menjadi $0,0566 \%$ dan peningkatan $\mathrm{pH}$ limbah cair tahu mencapai 6 - 7.

\section{Ucapan Terima Kasih}

Penulis mengucapkan terima kasih kepada RISTEK-BRIN atas pendanaan 
penelitian skema Penelitian Dosen Pemula (PDP) tahun 2020. Berdasarkan; 1) SK kuasa penggunaan anggaran Deputi Bidang Penguatan Riset dan Pengembangan Kementerian Riset dan Teknologi/ Badan Riset dan Inovasi Nasional nomor : 8/EI/KPT/2020 tentang Penetapan Pendanaan Penelitian di Perguruan Tinggi Tahun Anggaran 2020, 2) Kontrak penelitian antara DRPM dan LLDIKTI Wilayah VII nomor : 083/SP2H/LT/DRPM/2020， 3) Kontrak penelitian tahun tunggal antara LLDIKTI Wilayah VII dan Institut Ilmu Kesehatan Bhakti Wiyata Kediri nomor : 067/SP2H/LT-MONO/LL7/2020, 4)

Kontrak penelitian antara Institut Ilmu Kesehatan Bhakti Wiyata Kediri dan peneliti (penulis) nomor : 13/SP2H/LTMONO/IIK-BW/2020. Penulis juga mengucapkan terima kasih kepada IIK Bhakti Wiyata Kediri yang telah memberikan fasilitas dan bantuan untuk terlaksananya penelitian ini.

\section{Daftar Pustaka}

BPS Kota Kediri, 2018, Statistik Daerah Kota Kediri, BPS Kota Kediri

Fendri, S.T.J., Ifmaily, Syarti, S.R., 2019, Analisis Protein Pada Rinuak, Pensi dan Langkitang Dengan Spektrofotometri UV-Vis, Jurnal Katalisator, Vol 4 No. 2, 119-124

Gornall, A.G., Bardawill C.J., David M.M., 1949, Determination of Serum Proteins by Means of the Biuret Reaction, Journal of Biological Chemistry, Vol. 117, 751-766

Handayani, T and Niam, M.A., 2018, Pemanfaatan Limbah Tahu Sebagai Pupuk Cair Organik dan Es Krim Untuk Meningkatkan Pendapatan dan Pengembangan Produk, Jurnal Dedikasi, 16933214, 15

Iriana, D.D., Sedjati, S., Yulianto, B., 2018, Kemampuan Adsorbsi Kitosan Dari Cangkang Udang Terhadap Logam Timbal, Journal of Marine Research, Vol 7, No 4; 303-309

Jubaidah, S., Nurhasnawati, H., Wijaya, H., 2016, Penetapan Kadar Protein Tempe Jagung (Zea mays L.) Dengan Kombinasi Kedelai (Glycine max (L.) Merill) Secara Spektrofotometri Sinar Tampak, Jurnal Ilmiah Manuntung, 2(1), 111-119.

Kasman, M., Riyanti, A., Salmariza, Sy., Ridwan, M., 2018, Reduksi Pencemar Limbah Cair Industri Tahu dengan Tumbuhan Melati Air (Echinodorus palaefolius) Dalam Sistem Kombinasi Constructed Wetland dan Filtrasi, Jurnal Litbang Industri, 25025007

Kementerian Lingkungan Hidup, 2014, Peraturan Menteri Lingkungan Hidup Republik Indonesia Nomor 5 Tahun 2014 Tentang Baku Mutu Air Limbah, KEMEN-LH RI

Mardyaningsih, M., Leki, A., Rerung, O.D., 2014, Pembuatan Kitosan

Dari Kulit dan Kepala Udang Laut Perairan Kupang Sebagai Pengawet Ikan Teri Segar, Jurnal Rekayasa Proses, Vol 8, No 2

Mujtahidah, T., and Kusuma, B., 2019, The Influence of Concentration Liquid Waste of Tofu Production to Daphnia sp Cultivation Biomass, IJOTA, Vol 2, No 2; 67 72

Mulyaningsih, R., Sunarto, W., Prasetya, A.T., 2013, Peningkatan NPK Pupuk Organik Cair Limbah Tahu Dengan Penambahan Tepung Tulang Ayam, Sainteknol, Vol 11, No 1

Nastiti and Siahaan, P., 2015, Pengaruh Berat Molekul Kitosan Terhadap Efisiensi Enkapsulasi BSA (Bovine Serum Albumin) Menggunakan Agen Crosslink Na-TPP, Jurnal Kimia Sains dan Aplikasi, Vol 18, No 3; 104-109 
Pamungkas, A.W. and Slamet, A., 2017, Pengolahan Tipikal Instalasi Pengolahan Air Limbah Industri Tahu di Kota Surabaya, Jurnal Teknik ITS, 2337-3539, Vol 6., No. 2

Paramitha, D.A.P., 2017, Sifat Organoleptik Tahu Susu Dengan Jumlah Pemakaian Koagulan Yang Berbeda, PESONA, Vol 2, No 2; 2541-5859

Pradana, T.D., Suharno, Apriansyah, 2018, Pengolahan Limbah Cair Tahu Untuk Menurunkan Kadar TSS dan BOD, Jurnal Vokasi Kesehatan, 4 (2); 56 - 62

Pratiwi, H., Yusasrini, N.L.A., Putra, I.N.K., 2018, Pengaruh pH Ekstraksi Terhadap Rendemen, Sifat Fisiko-Kimia dan Fungsional Konsentrat Protein Kacang Gude (Cajanus cajan (L.) Millsp.), Jurnal ITEPA, Vol 7, No 1

Purnawan, C., Martini, T., Afidah, S., 2014, Penurunan Kadar Protein Limbah Cair Tahu Dengan Pemanfaatan Karbon Bagasse Teraktivasi, J. Manusia Dan Lingkungan, vol 21, no. 2, 143148

Putri, S.S. and Kartohardjono, S., 2018, Combination of Coagulationflocculation and Ultrafiltration Processes Using Cellulose Acetate Membrane for Wastewater Treatment of Tofu Industry, E3S Web of Conferences 67, EDP Sciences

Ravi Kumar M. N., 2000, A review of chitin and chitosan applications, React. Funct. Polym. 46, 1-27

Sarjono, P.R., Mulyani, N.S., Aminin, A.L.N., Wuryanti, 2006, Profil Kandungan Protein dan Tekstur
Tahu Akibat Penambahan Fitat Pada Proses Pembuatan Tahu, J. Kim. Sains \& Apl, vol IX, No 1

Seroja, R., Effendi, H., Hariyadi, S., 2018, Tofu Wastewater Treatment Using Vetiver Grass (Vetiveria zizanioides) and Zeliac, Applied Water Science, $8 ; 2$

Sinaga, S.M., Maria Intan, Jansen, S., 2015, Protein Analysis of Canned Legumes by using Visible Spectrophotometry and Kjeldahl Method, International Journal of PharmTech Research, Vol.8 No.6, 258-264

Vega, C., Elkana, D., Putri, O., Leonard, R., Andriyono, S., 2013, Rekayasa Chitosan Sebagai Pengawet dan Meningkatkan Kadar Protein Dalam Tahu, Jurnal Ilmiah Perikanan dan Kelautan, vol. 5 , no. 2

Yopianto, D., Sipangkar, M.J., Budiyanto, R., Siahaan, P., 2016, Studi Interaksi Antara Segmen Dimer Kitosan Dengan Peptida Ac-CA-NH ${ }_{2}$ dan Ac-TP-NH $\mathrm{NH}_{2}$ Secara Komputasi Ab-Initio, Jurnal Kimia Sains dan Aplikasi, Vol 19, No 3; 118-125

Yudhistira, B., Andriani, M., Utami, R., 2016, Karakterisasi : Limbah Cair Industri Tahu Dengan Koagulan Yang Berbeda (Asam Asetat dan Kalsium Sulfat), Caraka Tani Journal of Sustainable Agriculture, Vol. 31, No.2; 137145 